Jarvis Chelsea (Orcid ID: 0000-0002-8980-6398)

\title{
Advancement of winegrape maturity continuing for winegrowing regions in Australia with variable evidence of compression of the harvest period
}

\author{
C. JARVIS ${ }^{1, *}$, R. DARBYSHIRE ${ }^{1,2}$, I. GOODWIN ${ }^{3}$, E.W.R. BARLOW ${ }^{1}$ and R. \\ $\operatorname{ECKARD}^{1,3}$ \\ ${ }^{1}$ Faculty of Veterinary and Agricultural Sciences, University of Melbourne, Parkville, Vic. \\ 3010, Australia; ${ }^{2}$ NSW Department of Industry, Queanbeyan, NSW 2620, Australia; \\ ${ }^{3}$ Agriculture Victoria, Tatura, Vic. 3616, Australia
}

Corresponding author: Chelsea Jarvis, email chelsea.jarvis@usq.edu.au

*Current address: University of Southern Queensland, Toowoomba, Qld 4350, Australia

This is the author manuscript accepted for publication and has undergone full peer review but has not been through the copyediting, typesetting, pagination and proofreading process, which may lead to differences between this version and the Version of Record. Please cite this article as doi: 10.1111 /ajgw.12373

This article is protected by copyright. All rights reserved. 


\begin{abstract}
Background and Aims: Grapevine phenology is closely linked with growing season temperature. Rising temperature related to anthropogenic climate change has the potential to advance winegrape ripening. This study updated and validated previous research that considered changes to the timing of winegrape maturity and to the warming temperature of the growing season as well as added several new vineyard datasets. Length of the harvest period was assessed to determine if time between harvests of different cultivars has shortened.
\end{abstract}

Methods and Results: Vineyard records from 31 vineyard blocks in 13 Australian wine regions, in conjunction with gridded temperature data, were used to assess changes to maturity timing and mean growing season temperature. Trends toward earlier maturity were evident as were increases to mean growing season temperature for all vineyard blocks and regions considered. Trends varied in magnitude as well as by cultivar and region. Compression of the harvest period occurred for half of the regions studied. Conclusions: Winegrape maturity in Australia has continued to advance in line with warming temperature, which has implications for grape composition and wine quality. Compression of the harvest period was found in some cases, though varied by region and cultivars grown.

Significance of the Study: This study validated the trend towards earlier winegrape maturity with continued warming temperature and extended a valuable phenological dataset. 
In light of record warming, earlier maturity is becoming the new norm. The method used to investigate compression of the harvest period in this study is applicable to other winegrowing regions worldwide.

Keywords: climate change, phenology, vineyard, viticulture, warming temperature 


\section{Introduction}

Anthropogenic climate change is well documented and has been linked to changes in plant phenology due to warming temperature (Rosenzweig et al. 2008). Australia has experienced $0.4-0.7^{\circ} \mathrm{C}$ warming since 1950 , with the climate of the 21 st century projected as 'virtually certain' to be warmer with more extreme events (Intergovernmental Panel on Climate Change 2014b, p.1377). Winegrapes (Vitis vinifera), a perennial horticultural crop, are especially suitable for use in long-term phenological studies to consider the impact of climate change due to their longevity (20+ years) and sensitivity to climatic conditions which are reflected in phenological timing, and grape and wine composition (Jackson and Lombard 1993).

Timing of the phenological phases of winegrapes is closely related to climatic conditions during the growing season (Calò et al. 1995). Temperature has been shown to be the most important variable affecting phenology, with unusually warm temperature stimulating development and hastening the timing of physiological phases (Coombe 1987, Gladstones 1992, Parker et al. 2011). Increase in growing season temperature linked to anthropogenic climate change (Cook and Wolkovich 2016) has been shown to advance winegrape phenology, from budburst to maturity (Keller and Tarara 2010). For Australian wine regions, Webb et al. (2011) found trends in maturity timing averaging between -0.8 and -1.7 days per year, commensurate with an increase in mean growing season temperature. Similarly, Petrie and Sadras (2008) found advancement of winegrape maturity 
in Australia to be between -0.5 and -3.1 days per year and related these advancements to an increase in temperature.

Data which report trends in phenology in relation to temperature change, such as those highlighted above, are rarely subjected to further evaluation to ascertain whether reported trends are continuing, accelerating, or reversing. This process can provide validation of initial study conclusions or, indeed, highlight how more recent temperature conditions have modified phenological responses.

In conjunction with changes to maturity timing comes concerns about compression of the harvest period, where the time between when the first and last cultivars reach maturity is shortened (Webb et al. 2007). Warm temperature can hasten the time between phenological phases, such as from budburst to flowering, resulting in maturity occurring earlier in the season (e.g. Jones et al. 2005a, Bock et al. 2011, Malheiro et al. 2013). Generally, early-ripening cultivars, such as Chardonnay and Pinot Noir, reach maturity several weeks before later ripening cultivars, such as Cabernet Sauvignon. In a warming climate, a greater rate of advancement of maturity timing of some cultivars may shorten the time between when early cultivars are harvested relative to other cultivars (Webb et al. 2007). This can place pressure on vineyard and winery logistics, with all of the grapes needing to be harvested and processed over a shorter period. Many vineyard management service suppliers rely on seasonal workers and machines to help pick grapes according to a schedule. Should different cultivars all ripen around the same time, there may not be enough 
resources to pick the fruit at the optimum time, leading to suboptimal grape composition. Similarly, in the winery, a bottleneck can develop where there are not enough staff, equipment, and tank space to process and ferment the grapes in a timely fashion — all of which can compromise wine composition (Coulter et al. 2016).

The purpose of this study was to extend and compare results of temporal trends in previously collected winegrape maturity data and temperature data (Webb et al. 2011) with recently collected data. The winegrape maturity dataset was updated to include the vintages of 2010-2015 as well as new vineyard blocks to determine if previously reported trends were continuing and to ascertain if similar trends were found in newly acquired data. A method for assessing compression of the harvest period was investigated.

\section{Methods and materials}

\section{Vineyard data}

Pre-harvest and harvest winegrape sampling data that measured TSS ( ${ }^{\circ}$ Baumé) were collected and used to calculate a day of year of maturity (DOYM) (Table 1). Day of year of maturity was the day after 1 January that the grapes reached a designated TSS level. The TSS level was determined by vineyard block based on designations made by Webb et al. (2011) and Jarvis et al. (2017) and were converted to ${ }^{\circ}$ Brix (Table 1).

Vineyard records from 31 vineyard blocks in 13 Australian wine regions were used in this analysis (Table 1). Records for eight of those vineyard sites were used by Webb et al. 
(2011) and updated to 2015 for use here. Collected data from the majority of the vineyard sites (25/31) was at least 25 years or longer, the cut-off used by Webb et al. (2011) to define 'long-term' data sets.

\section{Temperature data used to calculate mean growing season temperature}

Gridded minimum and maximum daily temperature data $\left(0.05^{\circ} \times 0.05^{\circ}\right)$ from the Australian Bureau of Meteorology (Jones et al. 2009) were used to calculate mean growing season temperature (MGST) for each winegrowing region used in this study. Mean growing season temperature was calculated using the mean temperature for the months of October to April inclusive (Table 1) ('growing season') and is the same temperature metric that was used in Webb et al. (2011).

\section{Trend analysis for vineyard block DOYM and MGST}

Linear regression was used to determine temporal trends of DOYM and MGST with the margin of error at the $95 \%$ confidence level reported. Trends were calculated for the whole dataset at each vineyard as well as for the time frame of 1986-2015 for each region, to allow for a comparison of a common range of years between the current and the original study. 
Regional harvest compression analysis for vineyard sets

Regions that contained at least three vineyard blocks with different cultivars located in blocks adjacent to one another and had at least 25 years of data ('vineyard set') were selected for the study of harvest compression. The cultivar in the vineyard set with the earliest overall DOYM, the 'reference cultivar', was used as a reference point for other cultivars. If individual vineyards in the vineyard set had different years of data, only years common to the vineyard block used as the reference cultivar were used for the harvest compression analysis for that vineyard set. This contrasts with the method used by Webb et al. (2011), which compared changes in DOYM for all vineyards with data for the time frames of 1985-2009 and 1993-2009 and for all vineyards in a given region.

Compression of the harvest period was determined using linear regression to identify temporal trends. An anomaly ('harvest date anomaly') was determined by calculating the difference between the annual DOYM of the reference cultivar and annual DOYM of every other cultivar for every year in the series. For example, if the DOYM value of the reference cultivar was 73 in 1990 and the DOYM of Shiraz in the vineyard set was 103, the harvest date anomaly for the Shiraz for 1990 would be 30 . Harvest date anomaly values were then used in linear regression to determine if there were trends indicating harvest compression, with decreasing values over time of the harvest date anomaly indicating compression. If the harvest date anomaly was below zero, this would indicate that a previously later ripening cultivar had surpassed the harvest date of the earliest ripening cultivar for that vineyard set. 
Significance was set at $95 \%(P<0.05)$ and the margin of error at the $95 \%$ confidence level was reported. For vineyard sets longer than 1986-2015 two calculations of trends were made, one for all years of the dataset and another for the years of 1986-2015. 


\section{Results}

Temporal trends in DOYM

Every vineyard block included in this study showed a negative trend of DOYM over time, with $23 / 31$ results being statistically significant $(P<0.05)$, however, these trends differed in magnitude (Table 1). Significant earlier trends of DOYM ranged from -0.3 days per year (Rutherglen, Muscat Blanc à Petits Grains) to -1.6 days per year (Lower King Valley, Mondeuse).

\section{Updated long-term vineyards}

Eight vineyard blocks used by Webb et al. (2011) were updated to include the vintages of 2010 to 2015. Changes to trends in DOYM using all years of data up to 2015 found in this study were similar to those found by Webb et al. (2011) (Figure 1). One vineyard block, McLaren Vale, exceeded the margin of error found by Webb et al. (2011). The Mornington Peninsula Chardonnay vineyard block showed a slowing in DOYM rate of change, while all of the other blocks maintained or exceeded the rate of change found by Webb et al. (2011) [e.g. Central Victoria, Shiraz (2)], though these results were within the margin of error reported by Webb et al. (2011).

Trends in MGST 
All temporal trends in MGST were positive, though trend magnitude varied and not all were statistically significant $(P<0.05)$ (Table 2$)$. Rate of change varied between +0.01 and $+0.05^{\circ} \mathrm{C}$ per growing season. The three regions that did not have statistically significant trends in MGST for the time series that corresponded to the DOYM data (Hunter Valley, Coal River Valley Chardonnay block, and Upper King Valley) also had the least number of years of data used for the trend analysis (16, 18 and 19 years, respectively), indicating that there may have been insufficient years of data to determine statistical significance.

The trend of MGST for the 30 year period from 1986-2015 was calculated to provide a baseline by which to compare all regions. The rate of MGST was more rapid for this time period than for the longer time series that corresponded to years of DOYM. For example, the trend in MGST for McLaren Vale was $+0.01^{\circ} \mathrm{C}$ per growing season when all years in the DOYM time series were considered (1913-2015), whereas the slope was greater, $+0.04^{\circ} \mathrm{C}$ per growing season, when only the years of 1986-2015 were used.

Table 3 shows a comparison of average MGST for 1976-2005 (Webb et al. 2011) and for 1986-2015 for the five regions common to both studies. Four out of the five regions showed an increase in MGST while one showed a decrease (Central Victoria). The change to MGST between the two baseline periods was the greatest for Rutherglen, with an increase in MGST of $0.8^{\circ} \mathrm{C}$.

Compression of the harvest period 
Based on selection criteria for harvest compression analysis, which required at least three vineyard blocks of different cultivars in the same area with at least 25 years of data, four regions were selected for testing: Canberra District, Coonawarra, Central Victoria and Yarra Valley (Table 4). Evidence of harvest compression was mixed, with some vineyard sets showing a trend towards compression and other sets having non-significant compression $(P<0.05)$, no compression, or even trends away from compression (e.g. Canberra District Sémillon, Table 4).

Both the Central Victoria (Figure 2) and Yarra Valley vineyard sets showed evidence of compression. For Central Victoria, the two Shiraz blocks show a reduction in the harvest date anomaly relative to the Marsanne block (the reference cultivar). When all years in the vineyard set data were considered $(1940-2015)$, the only significant $(P<0.05)$ trend was for the Shiraz (1) block. For the time period of 1986-2015, however, both blocks showed significant compression relative to the Marsanne block, and the rate of compression was greater for both as compared to the rate found using all years in the data.

The Yarra Valley vineyard set also demonstrated harvest compression. At this site, the DOYM of fourcultivars (Cabernet Sauvignon, Marsanne, Merlot and Pinot Noir) was compared to the DOYM of Chardonnay, which was used as the reference cultivar, using the harvest date anomaly variable. While trends for all cultivars were negative, only two, Cabernet Sauvignon and Pinot Noir, were significant $(P<0.05)$ when all years $(1977-2015)$ 
were considered; however, only the trend for Cabernet Sauvignon was significant for the years of 1986-2015 (Table 4).

There was no observable harvest compression for the Coonawarra vineyard block set, which consisted of Cabernet Sauvignon and Merlot with Sauvignon Blanc used as the reference cultivar. The cultivars did not demonstrate any reduction in harvest date anomaly relative to the reference cultivar, indicating that time to maturity had not consistently shortened relative to Sauvignon Blanc. Positive trends were found for both Cabernet Sauvignon and Merlot (Table 4), however, neither trend was significant $(P<0.05)$.

Similar to Coonawarra, there was no harvest compression for the vineyard block set located in the Canberra Region. From 1990 to 2015, Cabernet Sauvignon, Sémillon, and Shiraz showed no clear trend towards compression over time in DOYM as compared to Pinot Noir. Rather, all cultivars showed a positive trend with the number of days increasing between maturity of Pinot Noir (reference cultivar) and the other cultivars, with the positive trend for Sémillon shown to be significant $(P<0.05)$.

\section{Discussion}

A trend towards earlier maturity and warmer growing season temperature was found for all vineyard blocks in this study, supporting results found in Webb et al. (2011). The magnitude of the trend varied by region and cultivar, indicating that changes over time were not uniform. Studies such as the one presented here are important for reviewing the impacts of 
climate change to determine if previously reported impacts are ongoing, accelerating, or have otherwise changed. A new methodology used to assess compression of the harvest period revealed that only select regions and cultivars showed a trend towards compression relative to the earliest ripening cultivar.

Overall, a trend towards earlier maturity was found to be consistent with that reported by Webb et al. (2011). Six of the eight vineyard blocks had rates of change that differed from those reported in the assessment by Webb et al. (2011), with five of the eight blocks showing an acceleration in advancement (Figure 1, e.g. McLaren Vale) and one, a decrease (Mornington Peninsula Chardonnay), though the majority (7/8) of these changes was within the margin of error. The greatest trend in DOYM ( -1.4 to -1.6 days per year) was found across a range of cultivars and climatic regions (Table 1), indicating that there was no consistency for these factors in relation to changes in DOYM. Rates found here were less than those reported by Petrie and Sadras (2008), which ranged from -0.5 to -3.1 days per year; however, a shorter time period was used in this study (1993-2006), which could account for the differences. Webb et al. (2011) also found that if a shorter period of time was used (1993-2009) rates of DOYM advancement increased. Vrsic and Vodovnik (2012) found all types of cultivars (early, mid and late ripening) were ripening earlier concomitant with an increase in temperature since 1980 for vineyards in Slovenia. Koufos et al. (2014) found a trend towards earlier maturity with warming temperature for a spatially diverse set of vineyards in Greece, however, impact was spatially dependent and varied by cultivar, 
with late-ripening cultivars appearing to be less impacted. Field trials using open top systems have been undertaken to explore the effect of increased temperature on grapevine phenology. Sadras and Soar (2009) found that elevating temperature during a single phenological stage did not significantly change maturity timing for Shiraz vineyards in Australia. Another Australian trial that considered impacts of temperature on maturity timing highlighted the importance of considering crop load, with less crop increasing the impact of temperature on maturity timing (Sadras and Moran, 2013).

In this study, the Margaret River region showed a trend towards early maturity $(-0.02$ days per growing season), however, it was not significant $(P<0.05)$. This differs from Webb et al. (2011) who found a positive trend in DOYM for this region $(+0.1$ days per growing season), though the trend was not significant. The average MGST for this region (Table 3) has increased by $0.3^{\circ} \mathrm{C}$ since the study done by Webb et al. (2011), which may account for this change in rate of DOYM. This example highlights the importance of reassessing studies focused on climate change, with new insight provided here using updated data.

Earlier ripening, represented as the decrease in DOYM found here, has been attributed to a combination of factors including warmer growing season temperature, lower soil moisture, and lower yield (Webb et al. 2012). Temperature has been shown to be best correlated to winegrape phenology and maturity timing, with warm temperature encouraging more rapid development (Jackson and Lombard 1993). Here we showed an increase in 
MGST, which could be related to earlier DOYM. For example, an increase in MGST of $1^{\circ} \mathrm{C}$ for the Central Victoria region would result in an advancement of DOYM by 14 days for Shiraz (1) and 11 days for Marsanne, based on data presented in this paper. This compares to an advancement of harvest date of 7.68 days per $1{ }^{\circ} \mathrm{C}$ that was reported for the Penedès region in Spain for the time frame of 1996-2009 (Camps and Ramos 2012), which was similar to findings in the Veneto region of Italy where a trend toward earlier maturity was estimated at 8 days per $1^{\circ} \mathrm{C}$ for the time period of 1964-2009 (Tomasi et al. 2011). Using data from 1600-2007, Cook and Wolkovich (2016) showed an advancement of 6 days per $1{ }^{\circ} \mathrm{C}$ temperature increase in winegrape maturity for vineyards in France and Switzerland. The advancement of winegrape maturity found here for Australia was of a greater magnitude than those reported for Europe; however, as mentioned previously, data sets differing in length and years included can influence rates of advancement, with data sets including more recent years usually having greater rates of advancement (Webb et al. 2007).

Jarvis et al. (2017) tested the correlation of maturity timing relative to climatic indices, and MGST was shown to be correlated to DOYM for vineyard blocks in Australia, indicating a link between MGST and DOYM. The relationship between temperature variables and maturity timing, however, is not necessarily linear, with extreme temperature, both hot and cold, delaying ripening (Coombe 1987). Similarly, changes to soil moisture can both hinder (too wet) and hasten (dry) ripening (Ramos et al. 2015). The Margaret River region, however, has for example, experienced significant drying due to a decrease in 
precipitation (Delworth and Zeng 2014), yet, as presented here, has seen little to no advancement of maturity timing, indicating that factors other than soil moisture likely have a greater influence over maturity timing. Crop load, or the amount of fruit per vine, also changes rate of ripening (Webb et al. 2012). If a vine is over-cropped (too much fruit), ripening will be delayed. If a vine is under-cropped (too little fruit), ripening will be hastened. While changes to crop load can influence maturity timing, Petrie and Sadras (2008) found that earlier maturity was unrelated to trends in yield in Australia.

Vineyard and winery operations can be impacted by earlier maturity. With earlier maturity timing, the grapes are likely to be picked during a warmer time of the year, which can compromise fruit quality (Webb et al. 2007). This was evident in Alsace, France, where warming temperature has led to an earlier start to the growing season, an earlier harvest with ripening occurring during a warmer time of the year, and a change to wine typicity which was associated with warmer temperature (Duchêne and Schneider 2005). In the winery, grapes with higher TSS from ripening in hotter vintages can lead to stuck fermentations (Coulter et al. 2016) and wines that are higher in alcohol (Godden and Gishen 2005).

At present, there are few easily implemented options to delaying winegrape maturity. Options tend to include delayed pruning or costly materials, such as change in clones, rootstocks, or cultivars. Delayed pruning until after budburst has been investigated as a possible solution to counter earlier vintages (Petrie et al. 2017). Apical buds will push before basal buds, so pruning after apical budburst removes the initial growth and forces the vine to 
develop lower buds, which takes time, thus delaying budburst. Using Sangiovese in Italy, delayed pruning was shown to postpone harvest timing, lower TSS in grapes, maintain higher acidity, and also have a positive effect on anthocyanin and phenolic substances (Frioni et al. 2016). Petrie et al. (2017) also found an improvement in berry composition with delayed pruning, along with the benefit of delayed maturity; however, the berry composition benefits of delayed pruning varied by season and cultivar. While delayed pruning may be an option for smaller vineyards, larger vineyards would struggle to prune all of their vines in a shortened window unless they hired extra staff. Clone or rootstock selection for slowing growth is another option for delaying maturity. Corso et al. (2016) found that ripening rates for Cabernet Sauvignon were more rapid when grafted to M4 rootstock as compared to $1103 \mathrm{P}$. Another option would be to change to a later-ripening cultivar more suited to warmer conditions, such as Cabernet Sauvignon or Mourvèdre. This option could help alleviate ripening during a hot time of the season and harvest compression. This approach, however, is not be applicable to regions where late-ripening cultivars are already grown (van Leeuwen and Destrac-Irvine 2017). Changing clones, rootstocks, or cultivars, however, would involve a greater financial input than delayed pruning.

All trends in mean growing season temperature found here were positive, indicating a warming growing season through time. Global trends in increasing temperature since the Industrial Revolution have been found to be caused by anthropogenic climate change (Intergovernmental Panel on Climate Change 2014a). The repercussions of warming MGST 
on winegrape growing depends on the magnitude of warming, current climatic conditions of a given region, and other climatic and non-climatic factors such as desired wine style. With continued warming temperature, there is likely to be a shift in areas suitable for quality wine production (Schultz and Jones 2010). Hall and Jones (2009) undertook spatial analysis of growing season temperature in Australia under different future climatic conditions and found that many northern areas will become too warm for winegrape production, including the Hunter Valley which was estimated to become unsuitable for quality wine production as early as 2030, though this estimate was based purely on temperature and does not incorporate possible adaptive capacities. Inland areas in Australia, especially, are expected to see a decline in wine quality due to increasing temperature (Webb et al. 2008). Conversely, areas in cool climates that are only able to fully ripen fruit in warm years (e.g. areas of Tasmania) may benefit from an increase in MGST, allowing more consistent ripening. This trend has also been documented in Europe, where colder regions previously considered marginal for wine production showed improved winegrape composition quality linked to warmer seasons (Lisek 2008).

In addition to shifts in areas of production, warming temperature will cause changes to berry and wine composition and typicity, including the concentration of sugars, acids, and flavonoids (Mira de Orduna 2010). Wine styles that help define a certain area rely on a specific climate (Jones 2012). A cultivar grown in a cool climate will have a different flavour profile to that grown in a warm climate. For example, Chardonnay from the 
Mornington Peninsula will have higher TA and lower alcohol than a Chardonnay from the Hunter Valley, which is likely to have more tropical flavours and be higher in alcohol. In a warming climate, the Mornington Peninsula Chardonnay used in this example may change in flavour and texture, losing its unique characteristics. Such a scenario has been reported for traditional cultivars in Germany, where a warming growing season was shown to have altered the ratio of sugar to acid in winegrapes, resulting in changes to wine flavour (Bock et al. 2011). Additionally, fruit from cultivars that prefer a cooler climate, such as Pinot Noir, may change in quality with an increase in MGST if grown in an area already marginal for that cultivar (Jones et al. 2005b). Wine scores have been linked to growing season temperature, with wine scores found to have a positive relationship with MGST to a certain threshold, above which the temperature was too warm for quality wine production (Jones 2006).

If changes to maturity dates advance more for one cultivar than another, especially late cultivars relative to early cultivars, harvest compression can occur. A novel approach to assessing harvest compression was used in this study, providing information about direction of the compression trend (positive or negative) and statistical significance of trend relative to a designated reference cultivar, which was selected based on the earliest cultivar to ripen during the growing season. This methodology could be applied to other winegrowing regions and cultivar sets. 
Vineyard block sets in the regions of Central Victoria and Yarra Valley in Victoria showed trends toward harvest compression, with later ripening cultivars, such as Cabernet Sauvignon, ripening earlier relative to the reference cultivar, such as Chardonnay. Both vineyard management and winery teams would be impacted by this compression, needing to pick and process multiple cultivars in a shorter amount of time than at the start of the dataset in 1982. In regards to the temporal changes to the harvest date anomaly for Pinot Noir relative to the reference cultivar Chardonnay, both are early ripening cultivars which would be expected to ripen around the same time.

The other two vineyard block sets in the Coonawarra and Canberra regions did not show any trend towards harvest compression and indeed had trends away from the reference cultivar, indicating that these cultivars, by the end of the data set in 2015 , were being picked later relative to the reference cultivar than at the beginning of each dataset. Based on trends in DOYM shown in Table 1, this finding of no compression for the vineyard set from Coonawarra was expected because the trend of DOYM for Cabernet Sauvignon was not statistically significant and the DOYM trends for Merlot and Sauvignon Blanc were nearly identical ( -1.0 and -1.1 days per year, respectively). As such, it follows that there was no indication of harvest compression for the Coonawarra block set. In the Canberra vineyard set, Pinot Noir had the largest trend in DOYM over time ( -1.4 days per year, Table 1$)$ as compared to the other cultivars. Thus, since Pinot Noir had the greatest trend, there was no harvest compression relative to this cultivar. This research supports findings by Webb et al. 
(2011) who also found harvest compression to be dependent on region and mix of cultivars. Petrie and Sadras (2008) reported finding a narrowing window of ripening and their initial results were supported by a follow up study (Petrie and Sadras 2016). While evidence exists that vintage compression is of concern (Coulter et al. 2015), further studies with additional regions and cultivars are needed to confirm findings.

\section{Conclusion}

This study extended and re-analysed a long-term viticultural database for Australian winegrowing regions that included 31 vineyard blocks representing a variety of economically important cultivars in 13 regions in order to determine if temporal trends in DOYM reported in Webb et al. (2011) using data up to the 2009 vintage were continuing from 2010 - 2015. Earlier DOYM was reported for all vineyard blocks included in this study, along with positive trends in MGST. Evidence of harvest compression was found for two out of four vineyard block sets, indicating that harvest compression may vary regionally and depend on the cultivars considered. This study highlighted the importance of updating and verifying previously used databases so as to assess the ongoing impacts of climate change. 


\section{Acknowledgements}

We thank Dr Leanne Webb and the wineries in Australia who provided access to their vineyard records. This study was supported by grants from Wine Australia (TP820332) and the University of Melbourne (681554).

\section{References}

Bock, A., Sparks, T., Estrella, N. and Menzel, A. (2011) Changes in the phenology and composition of wine from Franconia, Germany. Climate Research 50, 69-81.

Calò, A., Tomasi, D., Crespan, M. and Costacurta, A. (1995) Relationship between environmental factors and the dynamics of growth and composition of the grapevine. Acta horticulturae 427, 217-232.

Camps, J. O. and Ramos, M. C. (2012) Grape harvest and yield responses to inter-annual changes in temperature and precipitation in an area of north-east Spain with a Mediterranean climate. International Journal of Biometeorology 56, 853-864.

Cook, B. I. and Wolkovich, E. M. (2016) Climate change decouples drought from early wine grape harvests in France. Nature Climate Change 6, 715.

Coombe, B. G. (1987) Influence of temperature on composition and quality of grapes. Acta Horticulturae 206, 23-36.

Corso, M., Vannozzi, A., Ziliotto, F., Zouine, M., Maza, E., Nicolato, T., Vitulo, N., Meggio, F., Valle, G., Bouzayen, M., Müller, M., Munné-Bosch, S., Lucchin, M. and Bonghi, C. (2016) Grapevine rootstocks differentially affect the rate of ripening and modulate auxin-related genes in Cabernet Sauvignon berries. Frontiers in Plant Science 7, 69.

Coulter, A., Cowey, G., Petrie, P., Essling, M., Holdstock, M., Stockley, C., Simos, C. and Johnson, D. (2015) Vintage 2015 - observations from the AWRI helpdesk. Wine \& Viticulture Journal 30(4), 38-40.

Coulter, A., Cowey, G., Petrie, P., Essling, M., Holdstock, M., Stockley, C., Simos, C. and Johnson, D. (2016) Vintage 2016 - observations from the AWRI helpdesk. Wine \& Viticulture Journal 31(4), 43-45.

Delworth, T. L. and Zeng, F. (2014) Regional rainfall decline in Australia attributed to anthropogenic greenhouse gases and ozone levels. Nature Geoscience 7, 583. 
Duchêne, E. and Schneider, C. (2005) Grapevine and climatic changes: a glance at the situation in Alsace. Agronomy for sustainable development 25, 93-99.

Frioni, T., Tombesi, S., Silvestroni, O., Lanari, V., Bellincontro, A., Sabbatini, P., Gatti, M., Poni, S. and Palliotti, A. (2016) Postbudburst spur pruning reduces yield and delays fruit sugar accumulation in Sangiovese in Central Italy. American Journal of Enology and Viticulture 67, 419-425.

Gladstones, J. S. (1992) Viticulture and environment : a study of the effects of environment on grapegrowing and wine qualities, with emphasis on present and future areas for growing winegrapes in Australia (Winetitles: Adelaide, SA, Australia).

Godden, P. and Gishen, M. (2005) Trends in the composition of Australian wine. Australia and New Zealand Wine Industry Journal 20(5), 21-46.

Hall, A. and Jones, G. V. (2009) Effect of potential atmospheric warming on temperaturebased indices describing Australian winegrape growing conditions. Australian Journal of Grape and Wine Research 15, 97-119.

Intergovernmental Panel of Climate Change (2014a) Climate change 2014: impacts, adaptation, and vulnerability. Part A: Global and sectoral aspects. contribution of working group II to the fifth assessment report of the Intergovernmental Panel on Climate Change. Field, C.B., Barros, V.R., Dokken, D.J., Mach, K.J., Mastrandrea, M.D., Bilir, T.E., Chatterjee, M., Ebi, K.L., Estrada, Y.O., Genova, R.C., Girma, B., Kissel, E.S., Levy, A.N. , MacCracken, S., Mastrandrea, P.R. and White, L.L. , eds., (Cambridge University Press: Cambridge, England).

Intergovernmental Panel of Climate Change (2014b) Climate change 2014: impacts, adaptation, and vulnerability. Part B: Regional aspects. Contribution of working group II to the fifth assessment report of the Intergovernmental Panel on Climate Change, Barros, V.R., Field, C.B., Dokken, D.J., Mastrandrea, M.D., Mach, K.J., Bilir, T.E., Chatterjee, M., Ebi, K.L., Estrada, Y.O., Genova, R.C., Girma, B., Kissel, E.S., Levy, A.N., MacCracken, S., Mastrandrea, P.R. and White, L.L., eds. (Cambridge University Press: Cambridge, England).

Jackson, D. I. and Lombard, P. B. (1993) Environmental and management practices affecting grape composition and wine quality - a review. American Journal of Enology and Viticulture 44, 409-430.

Jarvis, C., Barlow, E., Darbyshire, R., Eckard, R. and Goodwin, I. (2017) Relationship between viticultural climatic indices and grape maturity in Australia. International Journal of Biometeorology 61, 1849-1862.

Jones, D. A., Wang, W. and Fawcett, R. (2009) High-quality spatial climate data-sets for Australia. Australian Meteorological and Oceanographic Journal 58, 233-248.

Jones, G., Duchene, E., Tomasi, D., Yuste, J., Braslavska, O., Schultz, H., Martinez, C., Boso, S., Langellier, F. and Perruchot, C. Changes in European winegrape phenology and relationships with climate. XIV International Groupe d'3/4ude des Systèmes de Conduite de la Vigne (GESCO) viticulture congress; 23-27 August 
2005; Geisenheim, Germany (Groupe d'Etude des Systèmes de Conduite de la Vigne: Geisenheim, Germany) 54-61.

Jones, G. V. 2006. Climate and terroir: impacts of climate variability and change on wine. Macqueen, R. W. andMeinert, L.D., eds. Fine wine and terroir - the geoscience perspective.( Geological Association of Canada: St John's, NL, Canada).

Jones, G. V. (2012) Climate, grapes, and wine: structure and suitability in a changing climate. Acta Horticulturae 931, 19-28.

Jones, G. V., White, M. A., Cooper, O. R. and Storchmann, K. (2005b) Climate change and global wine quality. Climatic Change 73, 319-343.

Keller, M. and Tarara, J. M. (2010) Warm spring temperatures induce persistent season-long changes in shoot development in grapevines. Annals of Botany 106, 131-141.

Koufos, G., Mavromatis, T., Koundouras, S., Fyllas, N. M. and Jones, G. V. (2014) Viticulture-climate relationships in Greece: the impacts of recent climate trends on harvest date variation. International Journal of Climatology 34, 1445-1459.

Lisek, J. (2008) Climatic factors affecting development and yielding of grapevine in central Poland. Journal of Fruit and Ornamental Plant Research 16, 285-293.

Malheiro, A. C., Campos, R., Fraga, H., Eiras-Dias, J., Silvestre, J. and Santos, J. A. (2013) Winegrape phenology and temperature relationships in the Lisbon wine region, Portugal. Journal International des Sciences de la Vigne et du Vin 47, 287-300.

Mira de Orduna, R. (2010) Climate change associated effects on grape and wine quality and production. Food Research International 43, 1844-1855.

Parker, A., De Cortázar-Atauri, I. G., Van Leeuwen, C. and Chuine, I. (2011) General phenological model to characterise the timing of flowering and veraison of Vitis vinifera L. Australian Journal of Grape and Wine Research 17, 206-216.

Petrie, P. and Sadras, V. (2016) Quantifying the advancement and compression of vintage. Australian \& New Zealand Grapegrower \& Winemaker (628), 40-41.

Petrie, P. R., Brooke, S. J., Moran, M. A. and Sadras, V. O. (2017) Pruning after budburst to delay and spread grape maturity. Australian Journal of Grape and Wine Research 23, 378-389.

Petrie, P. R. and Sadras, V. O. (2008) Advancement of grapevine maturity in Australia between 1993 and 2006: putative causes, magnitude of trends and viticultural consequences. Australian Journal of Grape and Wine Research 14, 33-45.

Ramos, M., Jones, G. and Yuste, J. (2015) Phenology and grape ripening characteristics of cv Tempranillo within the Ribera del Duero designation of origin (Spain): influence of soil and plot characteristics. European journal of agronomy, 70, 57-70.

Rosenzweig, C., Karoly, D., Vicarelli, M., Neofotis, P., Wu, Q., Casassa, G., Menzel, A., Root, T. L., Estrella, N., Seguin, B., Tryjanowski, P., Liu, C., Rawlins, S. and Imeson, A. (2008) Attributing physical and biological impacts to anthropogenic climate change. Nature 453, 353-357. 
Sadras, V. O. and Moran, M. A. (2013) Nonlinear effects of elevated temperature on grapevine phenology. Agricultural and forest meteorology 173, 107-115.

Sadras, V. O. and Soar, C. J. (2009) Shiraz vines maintain yield in response to a $2-4^{\circ} \mathrm{C}$ increase in maximum temperature using an open-top heating system at key phenostages. European Journal of Agronomy 31, 250-258.

Schultz, H. R. and Jones, G. V. (2010) Climate induced historic and future changes in viticulture. Journal of Wine Research, 21 137-145.

Tomasi, D., Jones, G. V., Giust, M., Lovat, L. and Gaiotti, F. (2011) Grapevine phenology and climate change: relationships and trends in the Veneto region of Italy for 19642009. American Journal of Enology and Viticulture 62, 329-339.

van Leeuwen, C. and Destrac-Irvine, A. (2017) Modified grape composition under climate change conditions requires adaptations in the vineyard. OENO One 51, 147-154.

Vrsic, S. and Vodovnik, T. (2012) Reactions of grape varieties to climate changes in North East Slovenia. Plant, Soil and Environment 58, 34-41.

Webb, L. B., Whetton, P. H. and Barlow, E. W. R. (2007) Modelled impact of future climate change on the phenology of winegrapes in Australia. Australian Journal of Grape \& Wine Research, 13, 165-175.

Webb, L. B., Whetton, P. H. \& Barlow, E. W. R. (2008) Climate change and winegrape quality in Australia. Climate Research 36, 99-111.

Webb, L. B., Whetton, P. H. and Barlow, E. W. R. (2011) Observed trends in winegrape maturity in Australia. Global Change Biology 17, 2707-2719.

Webb, L. B., Whetton, P. H., Bhend, J., Darbyshire, R., Briggs, P. R. and Barlow, E. W. R. (2012) Earlier wine-grape ripening driven by climatic warming and drying and management practices. Nature Climate Change 2, 259-264.

\section{Tables}

Table 1. Details of vineyard block datasets used for analysis.

Region

MGST
$\left({ }^{\circ} \mathrm{C}\right)$

Cultivar

Period of
data

Designated
maturity
$\left({ }^{\circ}\right.$ Brix)

Mean

Rate of change per year (DOYM) 


\begin{tabular}{|c|c|c|c|c|c|c|}
\hline \multirow{4}{*}{$\begin{array}{l}\text { Canberra District } \\
35.0^{\circ} \mathrm{S}, 149.0^{\circ} \mathrm{E}\end{array}$} & \multirow{4}{*}{17.5} & $\begin{array}{l}\text { Cabernet } \\
\text { Sauvignon }\end{array}$ & $\begin{array}{c}1986-2015 \\
(3) \S\end{array}$ & 21.6 & 90 & $-1.1 \pm 0.6 \dagger$ \\
\hline & & Pinot Noir & $\begin{array}{c}1986-2015 \\
\text { (3) }\end{array}$ & 21.6 & 74 & $-1.4 \pm 0.5 \dagger$ \\
\hline & & Sémillon & $\begin{array}{c}1986-2015 \\
\text { (5) }\end{array}$ & 19.8 & 84 & $-0.7 \pm 0.7$ \\
\hline & & Shiraz & $\begin{array}{c}1986-2015 \\
(2)\end{array}$ & 21.6 & 89 & $-1.0 \pm 0.8 \dagger$ \\
\hline \multirow{3}{*}{$\begin{array}{l}\text { Hunter Valley, } \\
\text { New South Wales } \\
32.8^{\circ} \mathrm{S}, 151.3^{\circ} \mathrm{E}\end{array}$} & \multirow{3}{*}{21.3} & Chardonnay & $2000-2015$ & 22.0 & 25 & $-0.9 \pm 1.0$ \\
\hline & & Sémillon (1) & $2000-2015$ & 19.8 & 35 & $-0.4 \pm 1.1$ \\
\hline & & Sémillon (2) & $2000-2015$ & 19.8 & 28 & $-0.3 \pm 1.0$ \\
\hline \multirow{2}{*}{$\begin{array}{l}\text { Barossa Valley, } \\
\text { South Australia } \\
34.6^{\circ} \mathrm{S}, 138.9^{\circ} \mathrm{E}\end{array}$} & \multirow{2}{*}{19.2} & $\begin{array}{c}\text { Cabernet } \\
\text { Sauvignon }\end{array}$ & $\begin{array}{l}1981-2015 \\
\text { (1) }\end{array}$ & 24.3 & 72 & $-0.6 \pm 0.5 \dagger$ \\
\hline & & Shiraz & 1979-2015 & 25.2 & 69 & $-1.0 \pm 0.5 \dagger$ \\
\hline \multirow{3}{*}{$\begin{array}{l}\text { Coonawarra, } \\
\text { South Australia } \\
37.2^{\circ} \mathrm{S}, 140.8^{\circ} \mathrm{E}\end{array}$} & \multirow{3}{*}{17.2} & $\begin{array}{c}\text { Cabernet } \\
\text { Sauvignon }\end{array}$ & $\begin{array}{c}1990-2015 \\
\text { (1) }\end{array}$ & 22.5 & 89 & $-0.7 \pm 0.7$ \\
\hline & & Merlot & $\begin{array}{c}1990-2015 \\
\text { (1) }\end{array}$ & 22.5 & 79 & $-1.0 \pm 0.6 \dagger$ \\
\hline & & Sauvignon Blanc & 1990-2015 & 19.8 & 60 & $-1.1 \pm 0.6 \dagger$ \\
\hline $\begin{array}{l}\text { McLaren Vale, } \\
\text { South Australia } \\
35.2^{\circ} \mathrm{S}, 138.6^{\circ} \mathrm{E} \ddagger\end{array}$ & 18.8 & Shiraz & $\begin{array}{c}1940-2010 \\
(10)\end{array}$ & 21.6 & 76 & $-0.5 \pm 0.2 \dagger$ \\
\hline \multirow{3}{*}{$\begin{array}{l}\text { Coal River } \\
\text { Valley, Tasmania } \\
42.7^{\circ} \mathrm{S}, 147.5^{\circ} \mathrm{E}+\end{array}$} & \multirow{3}{*}{15} & Chardonnay & $\begin{array}{c}1998-2015 \\
\text { (1) }\end{array}$ & 20.8 & 90 & $-1.1 \pm 1.6$ \\
\hline & & Pinot Noir (1) & $\begin{array}{l}1991-2015 \\
\text { (3) }\end{array}$ & 20.8 & 88 & $-1.3 \pm 0.8 \dagger$ \\
\hline & & Pinot Noir (2) & $\begin{array}{c}1992-2015 \\
\text { (5) }\end{array}$ & 20.8 & 80 & $-1.5 \pm 1.0 \dagger$ \\
\hline \multirow{3}{*}{$\begin{array}{l}\text { Central Victoria } \\
36.8^{\circ} \mathrm{S}, 145.1^{\circ} \mathrm{E}\end{array}$} & \multirow{3}{*}{18.5} & Marsanne & $\begin{array}{c}1940-2015 \\
\text { (5) }\end{array}$ & 18.0 & 67 & $-0.4 \pm 0.1 \dagger$ \\
\hline & & Shiraz (1) & $\begin{array}{c}1940-2015 \\
\text { (6) }\end{array}$ & 19.8 & 70 & $-0.4 \pm 0.1 \dagger$ \\
\hline & & Shiraz (2) & $\begin{array}{c}1959-2015 \\
\text { (1) }\end{array}$ & 19.8 & 68 & $-0.6 \pm 0.2 \dagger$ \\
\hline $\begin{array}{l}\text { Upper King } \\
\text { Valley, Victoria } \\
36.7^{\circ} \mathrm{S}, 146.3^{\circ} \mathrm{E}\end{array}$ & 17.4 & Chardonnay & $1997-2015$ & 19.8 & 51 & $-0.8 \pm 1.1$ \\
\hline
\end{tabular}

This article is protected by copyright. All rights reserved. 


\begin{tabular}{|c|c|c|c|c|c|c|}
\hline \multirow{2}{*}{$\begin{array}{l}\text { Lower King } \\
\text { Valley, Victoria } \\
36.5^{\circ} \mathrm{S}, 146.4^{\circ} \mathrm{E}\end{array}$} & \multirow{2}{*}{18.9} & Mondeuse & $\begin{array}{c}1986-2015 \\
(1)\end{array}$ & 22.5 & 89 & $-1.6 \pm 0.7 \dagger$ \\
\hline & & Shiraz & $1987-2015$ & 22.5 & 68 & $-1.0 \pm 0.6 \dagger$ \\
\hline \multirow{2}{*}{$\begin{array}{l}\text { Mornington } \\
\text { Peninsula, } \\
\text { Victoria } \\
38.4^{\circ} \mathrm{S}, 145.0^{\circ} \mathrm{E}+ \\
\end{array}$} & \multirow{2}{*}{16.8} & Chardonnay & $1985-2015$ & 20.8 & 90 & $-1.3 \pm 0.6 \dagger$ \\
\hline & & Pinot Noir & 1984-2015 & 20.8 & 85 & $-1.5 \pm 0.4 \dagger$ \\
\hline $\begin{array}{l}\text { Rutherglen, } \\
\text { Victoria } \\
36.0^{\circ} \mathrm{S}, 146.5^{\circ} \mathrm{E} \ddagger\end{array}$ & 19.5 & $\begin{array}{c}\text { Muscat Blanc à } \\
\text { Petits Grains }\end{array}$ & $\begin{array}{c}1945-2015 \\
(11)\end{array}$ & 27.0 & 72 & $-0.3 \pm 0.3 \dagger$ \\
\hline \multirow{5}{*}{$\begin{array}{l}\text { Yarra Valley, } \\
\text { Victoria } \\
37.7^{\circ} \mathrm{S}, 145.4^{\circ} \mathrm{E}\end{array}$} & \multirow{5}{*}{17.1} & Chardonnay & $1977-2015$ & 19.8 & 57 & $-0.4 \pm 0.3 \dagger$ \\
\hline & & $\begin{array}{c}\text { Cabernet } \\
\text { Sauvignon }\end{array}$ & $1973-2015$ & 21.6 & 90 & $-0.8 \pm 0.4 \dagger$ \\
\hline & & Marsanne & $\begin{array}{c}19732015 \\
(4)\end{array}$ & 19.8 & 79 & $-0.8 \pm 0.5 \dagger$ \\
\hline & & Merlot & 1978-2015 & 21.6 & 77 & $-0.5 \pm 0.4 \dagger$ \\
\hline & & Pinot Noir & 1973-2015 & 20.8 & 60 & $-0.5 \pm 0.2 \dagger$ \\
\hline $\begin{array}{l}\text { Margaret River, } \\
\text { Western Australia } \\
33.8^{\circ} \mathrm{S}, 115.0^{\circ} \mathrm{E} \ddagger\end{array}$ & 18.9 & $\begin{array}{l}\text { Cabernet } \\
\text { Sauvignon }\end{array}$ & $\begin{array}{c}1976-2015 \\
\text { (1) }\end{array}$ & 21.6 & 67 & $-0.02 \pm 0.4$ \\
\hline
\end{tabular}

$\dagger$ Significant trends $(P<0.05)$; Indicates datasets originally collected by Webb et al. (2011) and updated from 2010-2015 by Jarvis et al. (2017); § period of data missing. DOYM, day of year maturity.

Table 2. Temporal trends in mean growing season temperature for each unique duration of years of each vineyard block included in this study and for the time period of 1986-2015.

This article is protected by copyright. All rights reserved. 


\begin{tabular}{|c|c|c|c|}
\hline Region & Years & Trend MGST & $\begin{array}{c}\text { Trend MGST } \\
1986-2015\end{array}$ \\
\hline Canberra District & 1986-2015 & $0.04 \pm 0.03 \dagger$ & $0.04 \pm 0.03 \dagger$ \\
\hline Hunter Valley & 2000-2015 & $0.02 \pm 0.07$ & $0.02 \pm 0.02$ \\
\hline \multirow{2}{*}{ Barossa Valley } & 1981-2015 & $0.02 \pm 0.02 \uparrow$ & \multirow{2}{*}{$0.04 \pm 0.03 \dagger$} \\
\hline & 1979-2015 & $0.02 \pm 0.02 \dagger$ & \\
\hline Coonawarra & 1990-2015 & $0.04 \pm 0.03 \dagger$ & $0.03 \pm 0.03 \dagger$ \\
\hline McLaren Vale $\ddagger$ & $1913-2015$ & $0.01 \pm 0.005 \dagger$ & $0.04 \pm 0.02 \dagger$ \\
\hline \multirow{3}{*}{ Coal River Valley } & $-1998-2015$ & $0.01 \pm 0.04$ & \multirow{3}{*}{$0.02 \pm 0.02 \dagger$} \\
\hline & 1991-2015 & $0.03 \pm 0.03 \dagger$ & \\
\hline & 1992-2015 & $0.03 \pm 0.03 \dagger$ & \\
\hline \multirow{3}{*}{ Central Victoria $\ddagger$} & 1939-2015 & $0.02 \pm 0.01 \dagger$ & \multirow{3}{*}{$0.05 \pm 0.03 \dagger$} \\
\hline & 1940-2015 & $0.02 \pm 0.01 \dagger$ & \\
\hline & 1959-2015 & $0.02 \pm 0.01 \dagger$ & \\
\hline $\begin{array}{l}\text { King Valley } \\
\text { Upper }\end{array}$ & $1997-2015$ & $0.03 \pm 0.05$ & $0.04 \pm 0.03 \dagger$ \\
\hline \multirow{2}{*}{$\begin{array}{l}\text { King Valley } \\
\text { Lower }\end{array}$} & 1986-2015 & $0.04 \pm 0.03 \dagger$ & \multirow{2}{*}{$0.04 \pm 0.03 \dagger$} \\
\hline & 1987-2015 & $0.04 \pm 0.03 \dagger$ & \\
\hline \multirow{2}{*}{$\begin{array}{l}\text { Mornington } \\
\text { Peninsula } \$\end{array}$} & 1985-2015 & $0.03 \pm 0.02 \dagger$ & \multirow{2}{*}{$0.04 \pm 0.03 \dagger$} \\
\hline & 1984-2015 & $0.03 \pm 0.02 \dagger$ & \\
\hline Rutherglen $\ddagger$ & 1945-2015 & $0.01 \pm 0.01 \dagger$ & $0.05 \pm 0.03 \dagger$ \\
\hline \multirow{5}{*}{ Yarra Valley } & 1977-2015 & $0.02 \pm 0.02 \dagger$ & \multirow{5}{*}{$0.04 \pm 0.02 \dagger$} \\
\hline & 1973-2015 & $0.02 \pm 0.02 \dagger$ & \\
\hline & 1973-2015 & $0.02 \pm 0.02 \uparrow$ & \\
\hline & 1978-2015 & $0.02 \pm 0.02 \dagger$ & \\
\hline & 1973-2015 & $0.02 \pm 0.02 \dagger$ & \\
\hline Margaret River $\ddagger$ & 1976-2015 & $0.01 \pm 0.02$ & $0.03 \pm 0.03 \dagger$ \\
\hline
\end{tabular}

This article is protected by copyright. All rights reserved. 
Margin of error at the 95\% confidence interval and level of significance are included for each trend. $\uparrow$ Significant trends $(P<0.05)$. $\$$ Indicates datasets originally collected by Webb et al. (2011) and updated from 2010-2015 by Jarvis et al. (2017). MGST, mean growing season temperature.

Table 3. Comparison of mean growing season temperature reported by Webb et al. (2011) for the baseline 1976 - 2005 and mean growing season temperature used in this study with an updated baseline of $1986-2015$.

\begin{tabular}{|lcc|}
\hline Region & $\begin{array}{c}\text { MGST }\left({ }^{\circ} \mathbf{C}\right) \\
\text { 1976-2005 }\end{array}$ & $\begin{array}{c}\text { MGST }\left({ }^{\circ} \mathbf{C}\right) \\
\mathbf{1 9 8 6}-\mathbf{2 0 1 5}\end{array}$ \\
\hline Mornington Peninsula & 16.6 & 16.8 \\
\hline McLaren Vale & 18.4 & 18.8 \\
\hline Margaret River & 18.6 & 18.9 \\
\hline Rutherglen & 18.7 & 19.5 \\
\hline Central Victoria & 18.9 & 18.5 \\
\hline
\end{tabular}

MGST, mean growing season temperature. 
Table 4. Harvest compression trends for all years of data for the vineyard sets selected for testing and for the longer data sets, trends from 1986-2015.

\begin{tabular}{|ccc|}
\hline \multirow{2}{*}{ Region } & Cultivar & $\begin{array}{c}\text { Trend DOYM } \\
\text { all years }\end{array}$ \\
\hline \multirow{2}{*}{ Canberra District } & Cabernet Sauvignon & $0.3 \pm 0.4$ \\
\cline { 2 - 3 } & Sémillon & $0.7 \pm 0.6 \dagger$ \\
\cline { 2 - 3 } Coonawarra & Shiraz & $0.3 \pm 0.6$ \\
\cline { 2 - 3 } & Cabernet Sauvignon & $0.4 \pm 0.6$ \\
\hline \multirow{2}{*}{ Central Victoria } & Merlot & $0.1 \pm 0.5$ \\
\cline { 2 - 3 } & Shiraz (1) & $-0.1 \pm 0.1 \dagger$ \\
\hline \multirow{2}{*}{ Yarra Valley } & Shiraz (2) & $-0.1 \pm 0.1$ \\
\cline { 2 - 3 } & Cabernet Sauvignon & $-0.6 \pm 0.4 \dagger$ \\
\cline { 2 - 3 } & Marsanne & $-0.5 \pm 0.7$ \\
\cline { 2 - 3 } & Merlot & $-0.1 \pm 0.3$ \\
\cline { 2 - 3 } & Pinot Noir & $-0.2 \pm 0.2 \dagger$ \\
\hline
\end{tabular}

$\dagger$ Significant trends $(P<0.05)$.

This article is protected by copyright. All rights reserved. 


\section{Figure Legends}

Figure 1. Comparison of temporal trends of day of year maturity (DOYM) reported in the 'Current Study' (İ ) with those found in Webb et al. (2011) (Ï ) for the same vineyards. Data indicated here as 'Current Study' include the vintages of 2010-2015 in addition to all previous years. Significant trends $(P<0.05)$ are indicated by an asterisk. Cab. Sauv., Cabernet Sauvignon; Morn. Pen., Mornington Peninsula, Victoria; Vic., Victoria.

Figure 2. Vineyard set from Central Victoria, which included two Shiraz blocks [(1) (- - ; (2) (- $)$ ]and a Marsanne block that was used as the reference cultivar ( - at 0 ). Two time periods were used: all years in the data set $(-,-$,$) and 1986-2015 ((- - - , - - - )).$ 
The Harvest date anomaly is the year-by-year difference in number of days between the day of year maturity of Marsanne (the reference cultivar) and the other cultivars. 


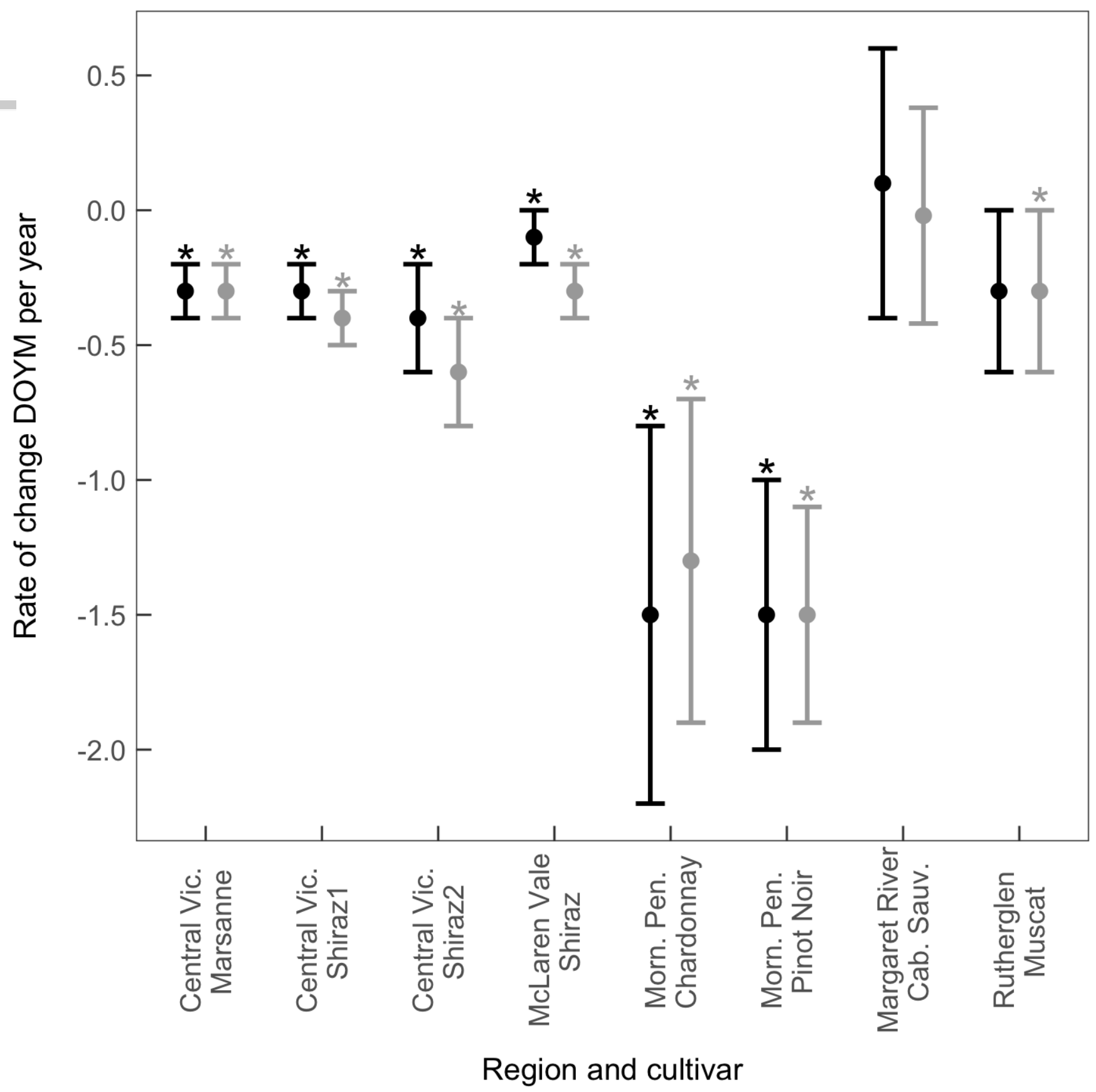

Jarvis_Figure1_Sep2018.tiff 


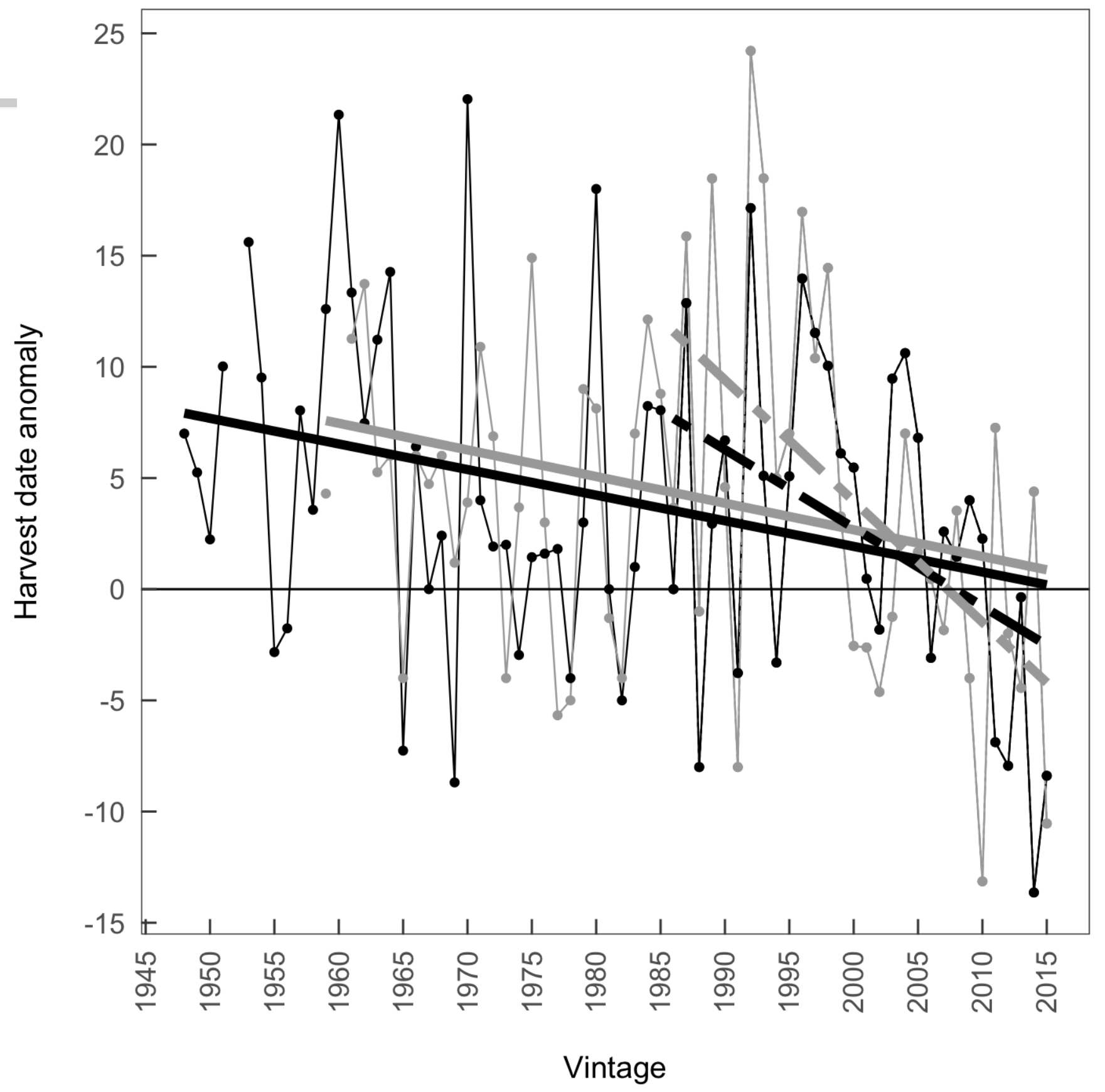

Jarvis_Figure2_Sep2018.tiff

This article is protected by copyright. All rights reserved. 


\section{University Library}

\section{- M M I N E R VA \\ A gateway to Melbourne's research publications}

Minerva Access is the Institutional Repository of The University of Melbourne

Author/s:

Jarvis, C;JARVIS, C;Darbyshire, R;Goodwin, I;Barlow, EWR;Eckard, R

Title:

Advancement of winegrape maturity continuing for winegrowing regions in Australia with variable evidence of compression of the harvest period

Date:

2019-01-01

Citation:

Jarvis, C., JARVIS, C., Darbyshire, R., Goodwin, I., Barlow, E. W. R. \& Eckard, R. (2019). Advancement of winegrape maturity continuing for winegrowing regions in Australia with variable evidence of compression of the harvest period. Australian Journal of Grape and Wine Research, 25 (1), pp.101-108. https://doi.org/10.1111/ajgw.12373.

Persistent Link:

http://hdl.handle.net/11343/284810 